\title{
SPECIFIC SURFACE, CRYSTALITE SIZE OF AIB12-NANO OF PRODUCTS OF INTERACTION "BN-Al" IN VACUUM
}

\author{
V. A. Petrova, V. V. Garbuz, V. B. Muratov, M. V. Karpets, T. A. Silinska, L. N. \\ Kuzmenko, T. N. Terentyeva, A. A. Vasiliev, P. V. Mazur, T. V. Khomko \\ Institute for Problems of Materials Science. I. Frantsevich National Academy of Sciences of \\ Ukraine, Krzhizhanovsky str., 3 Kyiv,03680,Ukraine, e-mail: wpetrowa@ukr.net; \\ Garbuz.v1950Gmail.com
}

\begin{abstract}
Boron carbide (BC, $B_{15-x} C_{x} B_{4} C$ ) has a unique combination of properties. This makes it a material for priority applications for a wide range of engineering solutions. The high melting point and heat resistance of the compound contribute to its use in refractory conditions. Due to its extreme abrasion resistance, $B_{4} C$ is used as an abrasive powder and coating. Due to its high hardness and low density, $B_{15-x} C_{x}$ has ballistic characteristics. It is usually used in nuclear programs as an absorbent of neutron radiation Boron carbide ceramics ( $B_{15-x} C_{x}$ or $B C$ ) may lose strength and toughness due to the amorphization effect under high shear stresses. Aluminum dodecaboride $A l B_{12}$ or $B_{12} A l$, as well as boron carbide $B_{12}\left[(C C C)_{x}(C B C)_{1-x}\right]$ have common structural units $B_{12}$ family of boron-icosahedral structures. The bond between icosahedrons is mainly due to atoms (Al, Si, O) or chains (CMC), where $M$ is Al, Si, B, C. Doping BC powder with a small amount of $A l B_{12}$, in cases of shock-shear stress, triggers the mechanism of "microcracking". Micro cracks and pores are formed in ceramics. The breakdown voltage decreases. $A_{12}$ synthesis is associated with known difficulties. On the other hand. The production of metal-ceramic materials for several decades is associated with the interaction of liquid aluminum and boron nitride. The calculation of this reaction shows that it is exothermic. Avoiding oxidation in vacuum, the reaction occurs through the formation of aluminum nitride and aluminum dodeca-boride. In contrast to the liquid state, the process continues until the end, at conditional temperatures of evaporation of aluminum with slight changes in vacuum. The reaction product is a mixture of nanosized AlN/AlB 12 powders with a weight ratio of $3 / 1$ ready for baking without grinding. The acid-base properties of the nanosized powder mixture AlN + $A l B_{12}$, the products of the interaction $B N+A l$ in vacuum, which are used optionally, emit separate in pure phases of aluminum nitride and aluminum dodeca-boride. The yield of AlB 12 is $\sim 25 \%$, boron reaches $\sim 100 \%$. The average particle size of the AlB 12 powders according to TEM and $A C S_{X \text {-rays }}$ (area of coherent $X$-rays scattering), $L(\mathrm{~nm})$ is $L_{T E M}=110-150 \mathrm{~nm}, L_{A C S}=51-70 \mathrm{~nm}$. The average specific surface area of the powder according to BET, TEM and ACS, $S_{\text {BET.m2/g }}=21,0-15,0 ; \quad S_{\text {TEM.m } / \mathrm{g}}=21,4-15,4 ; \quad S_{A C S . m 2 / g}=46,1-33,6 ; \quad(a t \quad 1460$ and $1640 K$, respectively) ${ }^{l}$.
\end{abstract}

Keywords: specific surface area, crystallite size, AlB 12 -nano powders, BN-Al aluminothermy, vacuum

The work was performed within the framework of NATO ESCD, SPS program No. 5070, "New shockresisting boron-based ceramics: computer modeling, production, testing". 


\section{Introduction}

Modern scientific and technological research of impact-resistant materials for over twenty years remains a priority in the use of reaction components and products of interaction in the systems: "Al - $\mathrm{BN}$ or $\mathrm{B}_{15-\mathrm{x}} \mathrm{C}_{\mathrm{x}}$ [1]" [2 - 8]. The method of vacuum aluminothermy of boron nitride brings the reaction to an end. A constant mass ratio of reaction products $\mathrm{AlN} / \mathrm{AlB}_{12}=1 / 3$ will not meet production needs. Therefore, the removal of individual compounds from the reaction mixture is relevant. In this work, we propose acid-base processing of reaction products prior to the extraction of $\mathrm{AlB}_{12}$ [9]. In the IPM of the NAS of Ukraine, the technology of obtaining a kilogram amount of a mixture of submicron powder $\mathrm{AlN} / \mathrm{AlB}_{12}=1 / 3$ was first developed. The practical use of this powder for the above-mentioned needs makes it possible to partially replace both expensive free boron, modify the charge of refractory carbide $\mathrm{B}_{12}$ [(C-B$\left.\mathrm{C})_{\mathrm{x}}(\mathrm{C}-\mathrm{C}-\mathrm{C})_{1-\mathrm{x}}\right]$ and to prevent of amorphous decomposition of ceramics. It is essential to facilitate up to hundreds of degrees of sintering regulations and prolong the operation of graphite equipment for hot pressing of dense ceramics without compromising the performance of products.

\section{Materials and research methods}

The production of submicron aluminum dodecaboride powders $[9,10]$ and carbon bonding products [11] has led to the adaptation of known methods of analysis of borides to a specific substance, such as $\mathrm{AlB}_{12}, \mathrm{AlB}_{40} \mathrm{C}_{4}, \mathrm{AlB}_{12} \mathrm{C}_{2}, \mathrm{Al}_{8} \mathrm{~B}_{4} \mathrm{C}_{7}$, or $\mathrm{A}_{14} \mathrm{~B}_{48} \mathrm{C}_{4}$. These methods include the determination of the main elements - boron and aluminum, as well as gas-forming and technological impurities, such as hydrogen, nitrogen, oxygen, carbon, water hardness elements, the amount of magnesium and calcium, as well as the presence of iron. If necessary, procedures for determining impurity phases of free boron, $\mathrm{B}_{2} \mathrm{O}_{3}$ and free carbon were tested [12 - 22]. Investigation of the porous structure of the samples was carried out using an ASAP 2000M (Accelerated Surface Area and Porosimeters System),]. Calculated specific surface by the method of BET $\left(\mathrm{S}_{\mathrm{BET}}, \mathrm{m}^{2} / \mathrm{g}\right)$. The method of roentgenography and transmission microscopy (PEM) in this work was used to determine the phase and size composition of $\mathrm{AlB}_{12}$ crystallites with using HZG-4A diffractometer, $\mathrm{Cu}-\mathrm{K} \alpha$ radiation with a Ni-filter and JEM $100 \mathrm{CX}$ instruments.

\section{Results and discussions}

The interaction products of boron nitride and aluminum are a mixture of powders of aluminum nitride and aluminum dodecaboride in the mass ratio $\mathrm{AlN} / \mathrm{AlB}_{12}=1 / 3$. The chemical properties of the formed compounds differ slightly in acid-base terms. It was found that the nanodimensional state of $\mathrm{AlN}$ and $\mathrm{AlB}_{12}$ enhances this difference, which made it possible to develop regulations for chemical treatment for the selective extraction of individual components of powders. Complex processing of intermediate technological solutions made it possible to obtain other useful materials. This applies to powders: $\mathrm{AlB}_{12}$; $\mathrm{AlN}$, as well as $\gamma-\mathrm{Al}_{2} \mathrm{O}_{3}$ and aqueous ammonia solution as by-products. Analysis of the interaction of synthesis products with mineral solvents, acids and alkalis are presented in Table 1. The interaction reaction is exothermic. Vacuum filtration of the precipitate using a Bunsen funnel and a Buchner flask. Washing with water to $\mathrm{pH} \sim 5$ (universal indicator). Washing with ethanol. Drying at $130^{\circ} \mathrm{C}$. Screening. Packing in dense container.

Extraction of $\mathrm{AlB}_{12}$ was performed by alkaline decomposition of $\mathrm{AlN}$ according to the equation of chemical reaction (1): 


$$
\mathrm{AlN}+\mathrm{AlB}_{12}+\mathrm{NaOH}+2 \mathrm{H}_{2} \mathrm{O} \rightarrow \mathrm{Na}\left[\mathrm{Al}(\mathrm{OH})_{4}\right]_{\text {solution }}+\mathrm{AlB}_{12} \downarrow_{\text {solid }}+\mathrm{NH}_{3} \uparrow \text { vapor }(1)
$$

Certification of $\boldsymbol{A l B}_{12}$. The synthesis of four batches of $\mathrm{AlB}_{12}$ powder in the field of external heating temperatures of the charge "BN+13Al" was carried out in order to determine the effect of temperature on the average particle size of the powder and the composition of the obtained aluminum dodecaboride. The results of the analysis of $\mathrm{AlB}_{12}$ powders are presented in Table 2. The atomic ratio of the main components and the content of gas-forming impurities are within acceptable limits regarding the quality of the obtained products. The average particle size $\left(\mathrm{L}_{\mathrm{AlB} 12}\right)$ and the specific surface area $\left(\mathrm{S}_{\mathrm{BET}}, \mathrm{m}^{2} / \mathrm{g}\right)$ of powders were determined and calculated. The obtained results are presented in the Table 3. The values of $L_{T E M}$ and $L_{A C S}$ differ almost twice. Calculation of the specific surface area $\left(\mathrm{S}_{\text {spesific }}, \mathrm{m}^{2} / \mathrm{g}\right)$ of the powder surface and comparison with $\mathrm{S}_{\mathrm{BET}}$ values showed that $\mathrm{S}_{\mathrm{TEM}}$ is closer to the experimental values. Moreover, obviously, the powders are somewhat agglomerated. The conglomerates of which are twice the minimum size of the average elementary particles of the studied samples (Table 3.)

Table 1. Products of system interaction: "AlB 12 solid $\downarrow+12 \mathrm{AlN}$ solid $\downarrow$ " with water, solutions of mineral acids and alkali

\begin{tabular}{|c|c|c|c|c|}
\hline $\mathrm{H}_{2} \mathrm{O}$ hot $\downarrow$ & $\mathrm{HNO}_{3}$ solution $\downarrow$ & $\mathrm{H}_{2} \mathrm{SO}_{4}$ solution $\downarrow$ & HCl solution $\downarrow$ & $\mathrm{NaOH}$ solution $\downarrow$ \\
\hline \multicolumn{5}{|c|}{$A l B_{12} \downarrow+A l N \downarrow$} \\
\hline AlB $_{12}$ hot $\downarrow$ & dissolved & dissolved & AlB $_{12}$ hot $\downarrow$ & AlB $_{12}$ hot $\downarrow$ \\
\hline $\begin{array}{l}\mathrm{NH}_{3} \uparrow g a s, \\
\mathrm{Al}(\mathrm{OH})_{3 \downarrow} \downarrow\end{array}$ & $\begin{array}{l}\mathrm{NH}_{4} \mathrm{NO}_{3}, \\
\mathrm{Al}_{(}\left(\mathrm{NO}_{3}\right)_{3} \\
\text { dissolved }\end{array}$ & $\begin{array}{l}\left.\mathrm{NH}_{4}\right)_{2} \mathrm{SO}_{4}, \\
\mathrm{Al}_{2}\left(\mathrm{SO}_{4}\right)_{3}, \\
\text { dissolved }\end{array}$ & $\begin{array}{c}\mathrm{NH}_{4} \mathrm{Cl}, \mathrm{AlCl}_{3} \\
\text { dissolved }\end{array}$ & $\begin{array}{c}\mathrm{NH}_{3} \uparrow \text { gas, } \\
\mathrm{Na}\left[\mathrm{Al}(\mathrm{OH})_{4}\right] \\
\text { dissolved }\end{array}$ \\
\hline
\end{tabular}

Table 2. Chemical (component) composition of $\mathrm{AlB}_{12}$ powders synthesized at temperatures of $1460-1600 \mathrm{~K}$

\begin{tabular}{|c|c|c|c|c|c|c|c|}
\hline №oo & $\mathrm{W}_{\mathrm{B}} \%$ & $\mathrm{~W}_{\mathrm{Al}} \%$ & $\mathrm{Al}$ \%ат. $/ \mathrm{B} \%$ aат. & $\mathrm{W}_{\mathrm{C}} \%$ & $\mathrm{~W}_{\mathrm{O}} \%$ & $\Sigma \mathrm{W}_{\mathrm{Ei}} \%$ & $\mathrm{~T} \mathrm{~K}$ \\
\hline 1 & 81.7 & 16.5 & $1 / 12.4$ & 0.23 & 0.68 & 99.1 & 1463 \\
\hline 2 & 81.9 & 17.1 & $1 / 12.0$ & 0.19 & 0.72 & 99.9 & 1533 \\
\hline 3 & 82.3 & 16.7 & $1 / 12.3$ & 0.18 & 0.60 & 99.8 & 1593 \\
\hline 4 & 81.9 & 17.2 & $1 / 11.9$ & 0.13 & 0.50 & 99.7 & 1643 \\
\hline
\end{tabular}


Table 3. Characteristics of the average particle size and specific area of the synthesized $\mathrm{AlB}_{12}$ powders at temperatures of $1460-1640 \mathrm{~K}$

\begin{tabular}{|c|c|c|c|c|c|}
\hline \multirow{2}{*}{$\begin{array}{c}\text { № sample } \\
\text { AlB }_{12} \text {, } \\
\text { T K } \\
\text { synthesis }\end{array}$} & \multicolumn{2}{|c|}{$\begin{array}{l}\text { The average particle size of } \\
\text { the powder according to TEM } \\
\text { and } \mathrm{ACS}_{\mathrm{X}-\mathrm{ray}}, \mathrm{L}(\mathrm{nm})\end{array}$} & \multicolumn{3}{|c|}{$\begin{array}{l}\text { The average specific surface area of the } \\
\text { powder according to BET and calculated } \\
\text { according to TEM and ACS X-ray }(\text { Area of } \\
\text { Coherent X-ray Scattering), } \mathrm{S}_{\text {specific. }}\left(\mathrm{m}^{2} / \mathrm{g}\right)\end{array}$} \\
\hline & $\mathrm{L}_{\text {TEM }}$ & L ACS, X-ray & $\begin{array}{r}\text { S } \mathrm{S}_{\mathrm{BET}} \\
\text { experiment }\end{array}$ & $\begin{array}{c}\text { S } \mathrm{S}_{\mathrm{BET}} \\
\text { experiment }\end{array}$ & $\begin{array}{l}\text { S } \text { ACS, X-ray } \\
\text { calculated }\end{array}$ \\
\hline $1(1460)$ & 110 & 51 & 21,0 & 21,4 & 46,1 \\
\hline $4(1640)$ & 150 & 70 & 15,0 & 15,7 & 33,6 \\
\hline
\end{tabular}

ACS - Area of coherent scattering X-ray of a single radiographic reflection hkl, the halfwidth of which is calculated by the average particle size of the powder $\mathrm{L}_{\mathrm{AlB} 12}$;

$\left(\mathrm{S}_{\mathrm{BET}},\left(\mathrm{m}^{2} / \mathrm{g}\right)\right)$, BET - specific surface area determined by the method of Brunauer S., Emmett P. H., Teller E. - BET [23 - 25];

$\mathrm{S}_{\mathrm{TEM}}, \mathrm{S}_{\mathrm{ACS}}$ X-ray - calculated according to $\mathrm{L}_{\mathrm{TEM}}$ and $\mathrm{L}_{\mathrm{ACS}}$, X-ray in a cubic orthogonal assumption; Where: $S_{\text {part }}=6 \mathrm{~L}^{2}$ - the average area of the particle;

$\mathrm{V}_{\text {part. }}=\mathrm{L}^{3}$ - average particle volume;

$\mathrm{N}_{\text {part }}=110^{-6} / \mathrm{cV}_{\text {part }}$, where $\mathrm{c}=2.55 \mathrm{~g} / \mathrm{cm}^{3}$ - the average number of particles in a volume occupying $1 \mathrm{~g}$ of $\mathrm{AlB}_{12}$ powder $\mathrm{cm}^{3} / \mathrm{c}$;

where $S_{\text {TEM }}, \operatorname{SACS}=\mathrm{S}_{\text {part }} \mathrm{n}_{\text {part }}\left(\mathrm{m}^{2} / \mathrm{g}\right)$.

$\mathrm{X}$-ray phase analysis is a single-phase product.

Syngony is tetragonal. Spatial group: $\mathrm{P} 4_{1} 2{ }_{1} 2 ; \mathrm{P} 4_{3} 2{ }_{1} 2 ; \mathrm{a}=1,016 ; \mathrm{c}=1,428(\mathrm{~nm})$, according to ICDD file No. 12 - 640 [26].

Morphology, according to TEM: transparent tetragonal planar crystals;

- average size: 60 - $40 \mathrm{~nm}$;

- maximum - 100 - $150 \mathrm{~nm}$.

The visual color of the powder is light brown.

The chemical composition and atomic ratio of the mass fractions of aluminum and boron is $\mathrm{W}_{\mathrm{Al}} / \mathrm{A}_{\mathrm{Al}}: \mathrm{W}_{\mathrm{B}} / \mathrm{A}_{\mathrm{B}}=1 / 11,9$, where $\mathrm{A}_{\mathrm{Al}}$ and $\mathrm{A}_{\mathrm{B}}$ are the atomic masses of aluminum and boron;

$\mathrm{W}_{\mathrm{O}}$ impurities $-0.3-0.5 \% ; \mathrm{W}_{\mathrm{N}}<10-2 \% ; \mathrm{W}_{\mathrm{H}}<10-2 \% ; \mathrm{W}_{\mathrm{C}}-0.2-0.5 \% ; \mathrm{W}_{\mathrm{Ca}} ; \mathrm{Mg} ; \mathrm{Fe} ; \mathrm{Si}<10-2 \%$ (wt.).

The experimentally established hardness (according to Vickers) of the sintered sample -0.75 $\mathrm{AlB}_{12}-0.25 \mathrm{AlN}$ is $26 \pm 2 \mathrm{GPa}$ at kilogram loads [9].

The obtained results indicate a certain stability and relative purity of the component composition of $\mathrm{AlB}_{12}$ powders in the range of synthesis temperatures $1463-1643 \mathrm{~K}$. The average particle size and specific surface area of the powder increases by $\sim 22 \%$. $\mathrm{AlB}_{12}$ particles are somewhat agglomerated. The average size of conglomerates does not exceed $150 \mathrm{~nm}$ and is twice as large as that of elementary particles of aluminum dodecaboride powder. The characteristics of the certification of aluminum dodecaboride powders are given below. 


\section{Conclusions}

Pure powders of $\mathrm{AlB}_{12}$-nano (40-60nm), AlN-nano (40nm) and $\Gamma-\mathrm{Al} 2 \mathrm{O} 3$-nano (4.0$10 \mathrm{~nm})$ were synthesized in significant quantities by chemical treatment of boron nitride vacuum aluminothermy products.

The work was performed within the framework of NATO ESCD, SPS program No. 5070, "New shock-resisting boron-based ceramics: computer modeling, production, testing".

\section{References}

1. Domnich V., Reynaud S., Haber R. A., Chhowalla M. Boron Carbide: structure; properties; and stability under stress. J. Am. Ceram. Soc. 2011. 94(11): 3605.

2. Stachin J. D., Pyzik A., Carrol D., Prunier A., Allen T. Boron Carbide Aluminum Cermet is for Pressure Housing Applications. Naval Command, Control and Ocean Surveillance Center. RDT\&E Division, San Diego, California 92152-5000, Technical Report 1574, September 1992: 192.

3. Yijun Du', Shuyou Li, K. Zhang', K. Lu' BN/Al composite formation by high-energy ball milling. Scrypta Materialia. 1997. 36(1): 7.

4. Ehsan Ghasali, Masoud Alizadeh, Touradj Ebadzadeh, Amir hossein Pakseresht, Ali Ranbari. Investigation on microstructural and mechanical properties of $\mathrm{B}_{4} \mathrm{C}$-aluminum matrix composites prepared by microwave sintering. J. Mater. Res. Technol. 2015. 4(4): 411.

5. Agus Pramono, Lembit Kommel, Lauri Kollo, Renno Veinthal. The Aluminum Based Composite Produced by Self-Propagating High Temperature Synthesis. Materials Science (Medziagotira). 2016. 22 (1): 1392.

6. Qian Zhao, Yunhong Liang, Zhihui Zhang, Xiujuan Li, Luguan Ren. Microstructure and Dry-Sliding Wear Behavior of $\mathrm{B}_{4} \mathrm{C}$ Ceramic Particulate Reinforced Al 5083 Matrix Composite. Metals. 2016. 6(227). 1; doi: 10.3390/met6090227

7. S. Wu, G. Xiao, L. Xue, L. Xue, M. Zhai, W. Zhu. Solid reaction between Al and B ${ }_{4}$. Canadian Metallurgical Quarterly. 2015. 54(2): 247.

8. Firestein K. L., Steinman F. E., Golovin I. S., Joan Cifre, Obraztsova E. A., Matveev A. T., Kovalskii A. M., Lebedev O. I. Fabrication, characterization and mechanical properties of spark plasma sintered Al - BN nanoparticle composites. Materials Science \& Engineering. 2015. 642: 104.

9. Patent UA, IPC (2016.01), C01B 35/04 (2016.01). Mazur, VB Muratov, VV Garbuz, EV Kartuzov, OO Vasiliev. Method for obtaining AlB12 aluminum dodecaboride powder. PV Patent for utility model №UA107193U; filed 11/26/2015; published 25.05.2016, Bull. № 10 .

10. Patent UA IPC (2016.01), C01B 35/04 (2016.01). Mazur, VB Muratov, VV Garbuz, EV Kartuzov, OO Vasiliev. Impact-resistant ceramics based on aluminum dodecaboride. PV №UA107259U; filed 15.12.2015; published 25.05.2016, Bull. № 10.

11. Ahmet Korogly, Derek P. Thompson Production of b-AlB $12, \mathrm{AlB}_{24} \mathrm{C}_{4}, \mathrm{AlB}_{12} \mathrm{C}_{2}$ and $\mathrm{Al}_{3} \mathrm{~B}_{48} \mathrm{C}_{2}$ powders in vacuum. Journal of the European Ceramic Society, 2012. 32. 3501.

12. Methods of chemical analysis of boron-containing refractory compounds. Pod. ed. TN Nazarchuk, Preprint №12, Kiev: IPM AN USSR.1984. 60.

13. Analysis of refractory compounds. Ed. GV Samsonova, M .: GNTILCHTsM, 1962.256

14. .Garbuz V.V. Methods of gas analysis. INORGANIC MATERIAL STUDIES: Encyclopedia. ed .: in 2 volumes floor. ed. V.V. Skorokhod, G.G. Gnesin. Kiev: Science. Dumka 2008. .1: Fundamentals of materials science. 858 (Ukrainian)

15. Wasserman A.M., Kunin L.L., Surovoy Yu. N. Determination of gases in metals. The method of reductive melting in the atmosphere of the carrier gas. M .: Nauka, 1976. 344. 
16. V.A. Dubok, V.I. Kornilova, L.E. Pechentkovskaya, E.V. Yukhimenko, G.T. Kabannik, V.V. Garbuz, G.Z. Omelchenko. Improvement of methods of chemical analysis of refractory compounds and metal alloys. Kiev: Scientific Opinion, 1988. 40 .

17. GOST 27417-87. Metal powders. Methods for determining oxygen. Publishing House of Standards. M 1988. 9

18. V.V. Garbuz, M.D. Bega, V.A. Petrova, L.S. Suvorova, L.M. Kuzmenko, S.K Shatskikh Study of oxidation of industrial powders of boron carbide by methods of chemical analysis Powder metallurgy. 2014. 7/8. 151(Ukrainian)

19. Zhibak T.M., Boychuk Yu. V., Bardakov B.V., Shkotova L.V., Duda T.I., Muratov V.B., Garbuz V..V, Vasiliev O.O., Korpan Ya. I., Biloivan O.A. Carbon nanomaterials: Investigation of characteristics and use in biosensor technology. Nanoscale systems and nanomaterials: research in Ukraine. Editorial Board: AG Naumovets (ed.); NAS of Ukraine. - K: Академпериодика 2014. 768 c. il. ISBN 978-966-360-260-8(Ukrainian)

20. Suvorova L.S., Petrova V.A., Lobunets T.F., Garbuz V.V. Determination of the surface of graphene-like boron nitride. Proceedings of IPM NAS of Ukraine, Series "Physico-chemical bases of powder materials technology" Modern problems of physical materials science. Issue 24.Kiev: 2015. 136.

21. Garbuz V.V., Kuzmenko L.M., Suvorova L.S., Petrova V.A., Silinskaya T.A., Shatskikh S.K. Quantitative determination by the method of selective oxidation of free carbon nanoforms in boron carbide powders. Powder metallurgy. 2016 1/2. 50.

22. F. Yu. Rachinsky, M.F. Rachinsky. Technique of laboratory works. Leningrad: Khimiya, 198. 432

23. Brunauer S. Adsorption of gases and vapors 1948. 1.783.

24. Poltorak O.M. Thermodynamics in physical chemistry. Higher school. 1991. 319

25. .Karnaukhov A.P. Adsorption. Texture of dispersed and porous materials. // Novosibirsk: Nauka. 1999. - 470 p.

26. Higashi I, Sakurai T, Atoda T. Crystal structure of a-AlB 12 Journal of Solid State Chemistry. Volume 20, Issue 1 1977. 67.

\title{
ПИТОМА ПОВЕРХНЯ, РОЗМІРИ КРИСТАЛІТІВ АІВ $12-N A N O$ ПРОДУКТІВ ВЗАСМОДІЇ "ВN-AI" У ВАКУУМІ
}

\author{
В. А. Петрова, В. В. Гарбуз, В. Б. Муратов, М. В. Карпець, Т. А. Силінська, Л. Н. \\ Кузьменко, Т. Н. Терентьєва, А. А. Васильєв, П. В. Мазур, Т. В. Хомко
}

Інститут проблем матеріалознавства ім. І. М. Францевича НАН України, вул. Кржижанівського, 3 Київ,

03680, Украина, e-mail: wpetrowa@ukr.net, Garbuz.v1950Gmail.com

Бору карбід (БК, $B_{15-x} C_{x} B_{4} C$ ) має унікальні поєднання властивостей. Це обумовлює його, як матеріал, щзодо пріоритетних застосувань для широкого кола інженерних рішень. Висока температура плавлення та термостійкість сполуки сприяє до застосування у вогнетривких умовах. Завдяки надзвичайній стійкості до стирання $B_{4} C$ використовують, як абразивні порошки та покриття. Завдяки високій твердості та низькій щільності, $B_{15-x} C_{x}$ відрізняється балістичними характеристиками. Зазвичай, він використовується в ядерних програмах, як абсорбент нейтронного випромінювання Кераміка бору карбіду $\left(B_{15-x} C_{x}\right.$ або БК) при дії високих зсувних напружень може втрачати 
мічність та в'язкість внаслідок ефекту аморфізачії. Додекаборид алюмінію AlB 12 або $B_{12} A l$, як $i$ бору карбід $B_{12}\left[(C C C)_{x}(C B C)_{1-x}\right]$ мають спільні структурні одиниці $B_{12}$ сімейства бор-ікосаедричних структур. Зв'язок між ними відбувається здебільше за рахунок атомів (Al, Si, O) або ланцюжків, (CMC), де $\mathrm{M}-\mathrm{Al}, \mathrm{Si}, \mathrm{B}$, C. Легування порошку БК невеликою кількістю $\mathrm{AlB}_{12}$, у випадках ударно-зсувного напруження, запускає механізм «мікро-крекінгу». Утворюються мікро тріщини та пори (cracks and pores) в кераміці. Напруга руйнування зменшується. Синтез AlB 12 пов'язано з відомими труднощами. 3 іншого боку. Виробництво металокерамічних матеріалів протягом декількох десятиліть пов'язане з взаємодією рідкого алюмінію та нітриду бору. Розрахунок теплоти реакції, показує, щзо вона екзотермічна. Уникаючи окислення у вакуумі, реакція відбувається иляхом утворення нітриду алюмінію та додекабориду алюмінію. На відміну від рідкого стану, процес триває до кіния, при умовних температурах випаровування алюмінію з незначними змінами вакууму. Продукт реакиї являє собою суміш нанорозмірних порошків AlN/AlB 12 із ваговим співвідношенням 3/1, готових до спікання без подрібнення. Кислотноосновні властивості нанорозмірної порошкової суміші AlN + AlB 12 , продуктів взаємодії $B N+A l$ у вакуумі в чистих фазах нітриду алюмінію та додекабориду алюмінію виділяють окремо. Вихід AlB 12 становить 25\%, по бору досягає 100\%. Середній розмір частинок порошків $\mathrm{AlB}_{12}$ за даними TEM та ОКР (рентгенівська область когерентного розсіювання), $L$ (нм) становить $L_{T E M}=110-150 \mathrm{Hм}$, LокP $=51-70 \mathrm{Hм}$. Середня питома поверхня порошку за ВЕТ, ТЕМ та ОКР, $S_{\text {ВET.M }}{ }^{2} / 2=21,0-15,0 ; S_{\text {TEM. }} M^{2} / 2=21,4-15,4$; $S_{\text {OKP }}$ $\mathrm{M}^{2} / 2=46,1-33,6$; (при 1460 mа 1640К відповідно).

Ключові слова: питома поверхня, розміри кристалітів, порошки AlB 12-нано, алюмотермія "BN-Al", вакуум 